\title{
Microbacterium halotolerans sp. nov., isolated from a saline soil in the west of China
}

Wen-Jun Li, ${ }^{1,2} \dagger$ Hua-Hong Chen, ${ }^{1,3} \dagger$ Chang-Jin Kim, ${ }^{2}$ Dong-Jin Park, ${ }^{2}$
Shu-Kun Tang, ${ }^{1}$ Jae-Chan Lee, ${ }^{2}$ Li-Hua Xu ${ }^{1}$ and Cheng-Lin Jiang ${ }^{1}$

Correspondence

Cheng-Lin Jiang

lihxu@ynu.edu.cn or

wjli@ynu.edu.cn

\author{
${ }^{1}$ The Key Laboratory for Microbial Resources of the Ministry of Education, Laboratory for \\ Conservation and Utilization of Bio-Resources, Yunnan Institute of Microbiology, Yunnan \\ University, Kunming, Yunnan, 650091, People's Republic of China \\ ${ }^{2}$ Korea Research Institute of Bioscience and Biotechnology, 52 Oeundong, Yusong, Daejeon \\ 305-333, Republic of Korea \\ ${ }^{3}$ Department of Chemistry, Chuxiong Normal College, Chuxiong, Yunnan, 675000, People's \\ Republic of China
}

\begin{abstract}
A Gram-positive short rod isolated from a saline soil in China was characterized using a polyphasic approach. This actinobacterium grew over a wide salinity range $[0-15 \% \mathrm{NaCl}$, $0-20 \% \mathrm{KCl}$ and $0-30 \% \mathrm{MgCl}_{2} \cdot 6 \mathrm{H}_{2} \mathrm{O}(\mathrm{w} / \mathrm{v})$; optimum concentrations for growth were $5 \%$ $\mathrm{NaCl}, 5-10 \% \mathrm{KCl}, 10 \% \mathrm{MgCl}_{2} \cdot 6 \mathrm{H}_{2} \mathrm{O}$ ]. The optimum growth temperature and $\mathrm{pH}$ were $28-30^{\circ} \mathrm{C}$ and $7 \cdot 0-8 \cdot 0$, respectively. Chemotaxonomic features (peptidoglycan-type B2 $\beta$ with glycolyl residues; major menaquinones MK-10 and MK-11; predominating iso- and anteiso-branched cellular fatty acids; DNA G $+\mathrm{C}$ content $66.5 \mathrm{~mol} \%$ ) placed this organism within the genus Microbacterium. 16S rRNA gene sequence analysis confirmed this classification of the strain, but showed that it was distinct from its nearest neighbours. It formed a separate branch with type strains of the genus Microbacterium, and also shared low sequence similarity with them ( $<96 \%)$. Based on phenotypic and molecular taxonomic results, it is proposed that the unknown isolate should be classified as a novel species in the genus Microbacterium, for which the name Microbacterium halotolerans sp. nov. is proposed. The type strain is YIM $70130^{\top}\left(=\right.$ KCTC $19017^{\top}=$ CIP $\left.108071^{\top}\right)$.
\end{abstract}

The genus Microbacterium was established by Orla-Jensen (1919) and comprises a diverse collection of Gram-positive, non-spore-forming rods. The description of the genus was emended by Collins et al. (1983). More recently, the genus Microbacterium was emended again to unite the genera Microbacterium and Aureobacterium (Takeuchi \& Hatano, 1998). Members of the genus Microbacterium can be isolated from a wide range of environmental habitats, including plants, soil, water, steep liquor, milk products and humans. Here, we describe the phenotypic and genotypic properties of a novel Microbacterium strain isolated from a saline habitat in the west of China.

Published online ahead of print on 9 July 2004 as DOI 10.1099/ ijs.0.63239-0.

†These authors contributed equally to the work.

The GenBank/EMBL/DDBJ accession number for the 16S rRNA gene sequence of strain YIM $70130^{\top}$ is AY376165.

Detailed phenotypic characteristics and a phylogenetic dendrogram of strain YIM $70130^{\top}$ and other Microbacterium species are available as supplementary material in IJSEM Online.
The strain used in this study was isolated from a saline soil from Qinghai Province, and is designated YIM 70130 ${ }^{\mathrm{T}}$. The strain was isolated using modified glycerol/asparagine agar (Shirling \& Gottlieb, 1966) (ISP5 medium) supplemented with $15 \%(w / v) \mathrm{KCl}$. The capacity for anaerobic growth was tested in a polystyrene jar using Anaerocult A (Merck) to create an anaerobic atmosphere. For chemotaxonomic and molecular systematic analysis, shake cultures were grown in modified trypticase soy broth (supplemented with $10 \%$, $\mathrm{w} / \mathrm{v}, \mathrm{KCl}, \mathrm{pH} 7 \cdot 0$ ) at $28{ }^{\circ} \mathrm{C}$ for 1 week before harvesting by centrifugation (10000 r.p.m. for 10 min; model J2-21 centrifuge; Beckman). Stocks of the strain were maintained routinely at $4{ }^{\circ} \mathrm{C}$ on modified trypticase soy agar slants containing $5-10 \% \mathrm{KCl}$ and as glycerol suspensions $(20 \%$, $\mathrm{v} / \mathrm{v})$ at $-20{ }^{\circ} \mathrm{C}$.

Cell and colony morphology were studied by light (Olympus microscope BH-2) and electron microscopy (JEOL JEM1010). Gram-staining and the $\mathrm{KOH}$ test were performed as described by Moaledj (1986). Motility of cells was studied by examining colony morphology on Luria-Bertani swarming agar $(0.3 \%, w / v)$. Growth at different temperatures, salt $\left(\mathrm{NaCl}, \mathrm{KCl}\right.$ and $\left.\mathrm{MgCl}_{2} \cdot 6 \mathrm{H}_{2} \mathrm{O}\right)$ concentrations and $\mathrm{pH}$ 
values was investigated as described by Tang et al. (2003). Growth temperatures employed ranged from 4 to $55^{\circ} \mathrm{C}$. Tolerance to $\mathrm{NaCl}, \mathrm{KCl}$ and $\mathrm{MgCl}_{2} \cdot 6 \mathrm{H}_{2} \mathrm{O}$ was tested at concentrations between 0 and $30 \%(\mathrm{w} / \mathrm{v})$ in combination with ISP5 medium. Growth was also tested at pH $5 \cdot 0-13 \cdot 0$.

Biochemical and physiological tests were performed using the methods described by Shirling \& Gottlieb (1966). Oxidase activity was investigated by examining oxidation of $1 \%$ benzidine (Deibel \& Ewans, 1960) and tetramethylp-phenylenediamine (Tarrand \& Groschel, 1982). Catalase activity was determined by bubble formation in a $3 \%$ ( $\mathrm{v} / \mathrm{v})$ hydrogen peroxide solution. Acid production from carbohydrates was determined as described by Leifson (1963). Substrate utilization and enzyme activities of the studied strains were determined using an API Coryne system and API ID $32 \mathrm{E}$ test kits (bioMérieux) according to the manufacturer's instructions.

The peptidoglycan structure was provided by the DSMZ identification service. Qualitative analyses of amino acids and peptides in peptidoglycan hydrolysates were carried out as described by Schleifer (1985) and Schleifer \& Kandler (1972) with the modification that TLC on cellulose was applied instead of paper chromatography. Quantitative analysis of amino acids in the total hydrolysate was performed by GC and GC-MS as described by MacKenzie (1987) and Groth et al. (1996). The $\mathrm{N}$ terminus of the interpeptide bridge was determined by dinitrophenylation according to Schleifer (1985).

Methods for the determination of cell-wall sugars, menaquinone patterns and fatty acids analysis followed those of Li et al. (2004a, b) and Chen et al. (2004).

The genomic DNA of the bacterium was extracted and purified by the method of Marmur (1961). The DNA G +C content of strain YIM $70130^{\mathrm{T}}$ was measured by the thermal denaturation method of Marmur \& Doty (1962).

The 16S rRNA gene sequence of the isolate was amplified by PCR using conserved primers close to the $3^{\prime}$ and $5^{\prime}$ ends of the gene, as described by Cui et al. (2001). Phylogenetic analysis was performed using the software packages PHYLIP (Felsenstein, 1993) and MEGA (Molecular Evolutionary Genetics Analysis) version 2.1 (Kumar et al., 2001) following multiple alignment of data using CLUSTAL_X (Thompson et al., 1997). Evolutionary distances (distance options according to the Kimura two-parameter model; Kimura, 1980, 1983) and clustering were calculated with the neighbour-joining (Saitou \& Nei, 1987) and maximumlikelihood (Felsenstein, 1981) methods. Bootstrap analysis was used to evaluate the tree topology of the neighbourjoining data by performing 1000 resamplings (Felsenstein, 1985).

Strain YIM $70130^{\mathrm{T}}$ is a Gram-positive, aerobic, non-motile, non-spore-forming, short rod (Fig. 1). Colonies are white,

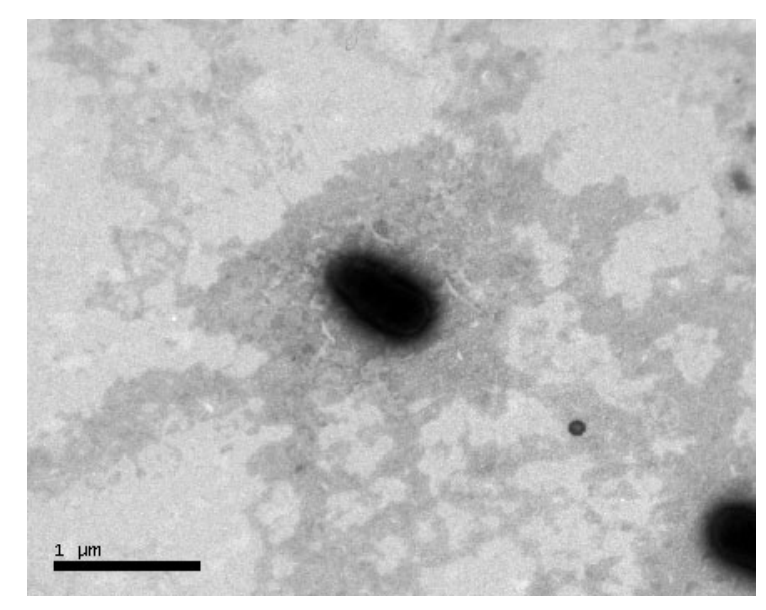

Fig. 1. Electron micrograph of strain $\mathrm{YIM} 70130^{\top}$ grown on modified ISP5 agar medium supplemented with $10 \%(\mathrm{w} / \mathrm{v}) \mathrm{KCl}$ for 2 days at $28^{\circ} \mathrm{C}$. Bar, $1 \mu \mathrm{m}$.

circular, convex with entire margins, shiny, moist and approximately $1-2 \mathrm{~mm}$ diameter after 48 h growth at $28^{\circ} \mathrm{C}$.

Physiological and biochemical characteristics, metabolic properties and substrate utilization results of strain YIM $70130^{\mathrm{T}}$ are given in detail in a table available as supplementary material in IJSEM Online and in the species description below.

Strain YIM $70130^{\mathrm{T}}$ contained ornithine, alanine, glycine, homoserine (Hsr), hydroxy-glutamic acid (Hyg) and small amounts of glutamic acid in the total hydrolysate of the peptidoglycan. From these data, we concluded that the peptidoglycan type was B2 $\beta$ (Schleifer \& Kandler, 1972), \{Gly\}[L-Hsr]D-Glu(Hyg)-Gly-D-Orn, with Gly at position 1 and L-Hsr at position 3 of the peptide subunit (type B6; DSMZ, 2001). Its cell-wall sugars contained ribose, galactose, glucose and trace amounts of xylose. The predominant

Table 1. Fatty acid composition of strain YIM $70130^{\top}$

\begin{tabular}{|lc|}
\hline Fatty acid & Content (\%) \\
\hline anteiso- $\mathrm{C}_{13: 0}$ & $0 \cdot 12$ \\
iso- $\mathrm{C}_{14: 0}$ & $0 \cdot 99$ \\
$\mathrm{C}_{14: 0}$ & $0 \cdot 18$ \\
anteiso A $\mathrm{C}_{15: 1}$ & $0 \cdot 75$ \\
iso- $\mathrm{C}_{15: 0}$ & $1 \cdot 19$ \\
anteiso- $\mathrm{C}_{15: 0}$ & $39 \cdot 91$ \\
$\mathrm{C}_{15: 0}$ & $0 \cdot 10$ \\
iso $\mathrm{G} \mathrm{C}_{16: 1}$ & $0 \cdot 34$ \\
iso- $\mathrm{C}_{16: 0}$ & $23 \cdot 40$ \\
$\mathrm{C}_{16: 0}$ & $1 \cdot 97$ \\
anteiso A $\mathrm{C}_{17: 1}$ & $0 \cdot 31$ \\
iso- $\mathrm{C}_{17: 0}$ & $0 \cdot 67$ \\
anteiso- $\mathrm{C}_{17: 0}$ & $30 \cdot 07$ \\
\hline
\end{tabular}


menaquinones were MK-10 and MK-11. The cellular fatty acid composition of strain YIM $70130^{\mathrm{T}}$ is given in Table 1.

To ascertain its phylogenetic position, the almost-complete $16 \mathrm{~S}$ rRNA gene sequence (1492 nt) for strain YIM $70130^{\mathrm{T}}$ was determined. A phylogenetic tree (available as supplementary material in IJSEM Online) demonstrated that the isolate is a member of the genus Microbacterium, and that it formed an independent phyletic line within a monophyletic subclade. 16S rRNA gene sequence similarity values of the isolate to all of the Microbacterium species ranged from $93 \cdot 8 \%$ (Microbacterium imperiale) to $96 \cdot 3 \%$ (Microbacterium kitamiense). It is clear from phylogenetic analyses based on nearly complete $16 \mathrm{~S}$ rRNA gene sequences that the isolate belongs to the genus Microbacterium and represents a distinct phyletic line that can be equated to a separate genomic species (Stackebrandt \& Goebel, 1994).

Strain YIM $70130^{\mathrm{T}}$ shares some chemotaxonomic features with members of the genus Microbacterium; i.e. the cellwall peptidoglycan type is $\mathrm{B} 2 \beta$, major menaquinones are MK-10 and MK-11, iso- and anteiso-branched cellular fatty acids predominate and the DNA G $+\mathrm{C}$ content is $66.5 \%$. However, it shows considerable phenotypic and genomic differences with other recognized species of the genus Microbacterium. We propose that strain YIM70130 represents a novel species of the genus Microbacterium, Microbacterium halotolerans sp. nov.

\section{Description of Microbacterium halotolerans sp. nov.}

Microbacterium halotolerans (ha.lo.to'le.rans. Gr. n. halos salt; L. part. tolerans tolerating; N.L. part. adj. halotolerans referring to the ability of the organism to tolerate high salt concentrations).

Aerobic, Gram-positive, non-motile, non-spore-forming, short rod. Colonies are white, circular, convex with entire margins, shiny, moist and approximately 1-2 mm diameter after $72 \mathrm{~h}$ at $28^{\circ} \mathrm{C}$. Can grow in ISP5 medium containing $0-15 \% \mathrm{NaCl}, 0-20 \% \mathrm{KCl}$ or $0-30 \% \mathrm{MgCl}_{2} \cdot 6 \mathrm{H}_{2} \mathrm{O}$; optimum concentrations for growth are $5 \% \mathrm{NaCl}, 5-10 \%$ $\mathrm{KCl}, 10 \% \mathrm{MgCl}_{2} \cdot 6 \mathrm{H}_{2} \mathrm{O}$. Optimum growth temperature and $\mathrm{pH}$ are $28-30{ }^{\circ} \mathrm{C}$ and $7 \cdot 0-8 \cdot 0$, respectively. Catalasepositive and oxidase-negative. Tweens 20 and 80, gelatin, casein and starch are not decomposed. Voges-Proskauer test, $\mathrm{H}_{2} \mathrm{~S}$ production and indole production are negative. Nitrate is not reduced to nitrite. Activities for lipase, $\beta$-glucosidase, $\beta$-galactosidase and $\alpha$-maltosidase are positive. Negative for ornithine decarboxylase, arginine dihydrolase, lysine decarboxylase, urease, $\alpha$-galactosidase, $N$-acetyl- $\beta$-glucosaminidase, $\beta$-glucosidase, $\beta$-glucuronidase, $\alpha$-maltosidase and L-aspartic arylamidase. Uses the following compounds as sole carbon and energy sources: glucose, mannitol, mannose, ribose, fructose, sucrose, maltose, galactose, arabinose, starch, cellobiose, lactose and xylose. Amygdalin, salicin, dextrin, galacturonate, 5-ketogluconate, L-arabitol, trehalose, rhamnose, inositol, sorbitol, malonate and adonitol can not be assimilated. Acid is produced from glucose, mannitol, mannose, ribose, fructose, maltose and xylose. The peptidoglycan type is $\mathrm{B} 2 \beta$, $\{\mathrm{Gly}\}[\mathrm{L}-\mathrm{Hsr}] \mathrm{D}-$ Glu(Hyg)-Gly-D-Orn, with glycolyl residues. Cell sugars contain ribose, galactose, glucose and trace amounts of xylose. The predominant menaquinones are MK-10 and MK-11. The major cellular fatty acids are anteiso- $\mathrm{C}_{15: 0}$ $(39 \cdot 91 \%)$, anteiso- $\mathrm{C}_{17: 0}(30 \cdot 07 \%)$ and iso- $\mathrm{C}_{16: 0}(23 \cdot 40 \%)$. The DNA G $+\mathrm{C}$ content is $63 \cdot 8 \mathrm{~mol} \%$.

The type strain, YIM $70130^{\mathrm{T}}\left(=\mathrm{KCTC} 19017^{\mathrm{T}}=\mathrm{CIP}\right.$ $108071^{\mathrm{T}}$ ), was isolated from saline soil collected from Qinghai Province in the west of China.

\section{Acknowledgements}

This research was supported by the National Basic Research Program of China (2004CB719600), Chinese National Natural Science Foundation (30270004), Yunnan Provincial Natural Science Foundation (2001C0001Q and 2004C0002Q), Yunnan Education Commission Foundation (02QJ077), China, and the 21C Frontier Microbial Genomics and Application Center Program, Ministry of Science \& Technology (MG02-0101-002-1-0-0), the International Cooperation R \& D Program, Ministry of Science \& Technology (M6-0203-000002), Korea.

\section{References}

Chen, H.-H., Li, W.-J., Tang, S.-K., Kroppenstedt, R. M., Stackebrandt, E., Xu, L.-H. \& Jiang, C.-L. (2004). Corynebacterium halotolerans sp.nov., isolated from saline soil in the west of China. Int J Syst Evol Microbiol 54, 779-782.

Collins, M. D., Jones, D. \& Kroppenstedt, R. M. (1983). Reclassification of Brevibacterium imperiale (Steinhaus) and "Corynebacterium laevaniformans" (Dias and Bhat) in a redefined genus Microbacterium (Orla-Jensen) as Microbacterium imperiale comb. nov. and Microbacterium laevaniformans nom. rev.; comb. nov. Syst Appl Microbiol 4, 65-78.

Cui, X.-L., Mao, P.-H., Zeng, M., Li, W.-J., Zhang, L.-P., Xu, L.-H. \& Jiang, C.-L. (2001). Streptimonospora salina gen. nov., sp. nov., a new member of the family Nocardiopsaceae. Int J Syst Evol Microbiol 51, 357-363.

Deibel, R. H. \& Ewans, J. B. (1960). Modified benzidine test for the detection of cytochrome-containing respiratory systems in microorganisms. J Bacteriol 79, 356-360.

DSMZ (2001). Catalogue of Strains, 7th edn. Braunschweig: Deutsche Sammlung von Mikroorganismen und Zellkulturen.

Felsenstein, J. (1981). Evolutionary trees from DNA sequences: a maximum likelihood approach. J Mol Evol 17, 368-376.

Felsenstein, J. (1985). Confidence limits on phylogenies: an approach using the bootstrap. Evolution 39, 783-791.

Felsenstein, J. (1993). PHYLIP (phylogeny inference package), version 3.5. Department of Genetics, University of Washington, Seattle, USA.

Groth, I., Schumann, P., Weiss, N., Martin, K. \& Rainey, F. A. (1996). Agrococcus jenensis gen. nov., sp. nov., a new genus of actinomycetes with diaminobutyric acid in the cell wall. Int $J$ Syst Bacteriol 46, 234-239.

Kimura, M. (1980). A simple method for estimating evolutionary rates of base substitutions through comparative studies of nucleotide sequences. J Mol Evol 16, 111-120. 
Kimura, M. (1983). The Neutral Theory of Molecular Evolution. Cambridge: Cambridge University Press.

Kumar, S., Tamura, K., Jakobsen, I. B. \& Nei, M. (2001). MEGA2: Molecular Evolutionary Genetics Analysis software. Bioinformatics 17, 1244-1245.

Leifson, E. (1963). Determination of carbohydrate metabolism of marine bacteria. J Bacteriol 85, 1183-1184.

Li, W.-J., Chen, H.-H., Xu, P., Zhang, Y.-Q., Schumann, P., Tang, S.-K., Xu, L.-H. \& Jiang, C.-L. (2004a). Yania halotolerans gen. nov., sp. nov., a novel member of the suborder Micrococcineae from saline soil in China. Int J Syst Evol Microbiol 54, 525-531.

Li, W.-J., Chen, H.-H., Zhang, Y.-Q., Schumann, P., Stackebrandt, E., Xu, L.-H. \& Jiang, C.-L. (2004b). Nesterenkonia halotolerans sp. nov. and Nesterenkonia xinjiangensis sp. nov., actinobacteria from saline soils in the west of China. Int J Syst Evol Microbiol 54, 837-841.

MacKenzie, S. L. (1987). Gas chromatographic analysis of amino acids as the $N$-heptafluorobutyryl isobutyl esters. J Assoc Anal Chem 70, 151-160.

Marmur, J. (1961). A procedure for the isolation of deoxyribonucleic acid from microorganisms. J Mol Biol 3, 208-218.

Marmur, J. \& Doty, P. (1962). Determination of base composition of deoxyribonucleic acid from its denaturation temperature. J Mol Biol 5, 109-118.

Moaledj, K. (1986). Comparison of Gram-staining and alternate methods, $\mathrm{KOH}$ test and aminopeptidase activity in aquatic bacteria: their application to numerical taxonomy. J Microbiol Methods 5, 303-310.

Orla-Jensen, S. (1919). The Lactic Acid Bacteria. Copenhagen: Host \& Sons.
Saitou, N. \& Nei, M. (1987). The neighbor-joining method: a new method for reconstructing phylogenetic trees. Mol Biol Evol 4, 406-425.

Schleifer, K. H. (1985). Analysis of the chemical composition and primary structure of murein. Methods Microbiol 18, 123-156.

Schleifer, K. H. \& Kandler, O. (1972). Peptidoglycan types of bacterial cell walls and their taxonomic implications. Bacteriol Rev 36, 407-477.

Shirling, E. B. \& Gottlieb, D. (1966). Methods for characterization of Streptomyces species. Int J Syst Bacteriol 16, 313-340.

Stackebrandt, E. \& Goebel, B. M. (1994). Taxonomic note: a place for DNA-DNA reassociation and $16 \mathrm{~S}$ rRNA sequence analysis in the present species definition in bacteriology. Int J Syst Bacteriol 44, 846-849.

Takeuchi, M. \& Hatano, K. (1998). Union of the genera Microbacterium Orla-Jensen and Aureobacterium Collins et al. in a redefined genus Microbacterium. Int J Syst Bacteriol 48, 739-747.

Tang, S.-K., Li, W.-J., Wang, D., Zhang, Y.-G., Xu, L.-H. \& Jiang, C.-L. (2003). Studies of the biological characteristics of some halophilic and halotolerant actinomycetes isolated from saline and alkaline soils. Actinomycetological 17, 6-10.

Tarrand, J. J. \& Groschel, D. H. M. (1982). Rapid, modified oxidase test for oxidase-variable bacterial isolates. J Clin Microbiol $\mathbf{1 6}$ 772-774.

Thompson, J. D., Gibson, T. J., Plewniak, F., Jeanmougin, F. \& Higgins, D. G. (1997). The CLUSTAL_X Windows interface: flexible strategies for multiple sequence alignment aided by quality analysis tools. Nucleic Acids Res 25, 4876-4882. 